\section{Cognitive Construal-Consistent Instructor Language in the Undergraduate Biology Classroom}

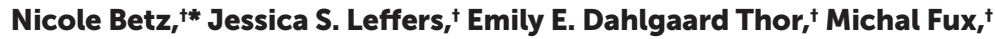 \\ Kristin de Nesnera, ${ }^{\ddagger}$ Kimberly D. Tanner ${ }^{\S}$, and John D. Coley ${ }^{\dagger}$ \\ 'Department of Psychology, Northeastern University, Boston, MA 02115-5000; 'Department of \\ Biology, College of Science, Utah Valley University, Orem, UT 84058; "Department of Biology, \\ San Francisco State University, San Francisco, CA 94132
}

\begin{abstract}
Researchers have identified patterns of intuitive thinking that are commonly used to understand and reason about the biological world. These cognitive construals (anthropic, teleological, and essentialist thinking), while useful in everyday life, have also been associated with misconceptions about biological science. Although construal-based thinking is pervasive among students, we know little about the prevalence of construal-consistent language in the university science classroom. In the current research, we characterized the degree to which construal-consistent language is present in biology students' learning environments. To do so, we coded transcripts of instructor's speech in 90 undergraduate biology classes for the presence of construal-consistent language. Classes were drawn from two universities with very different student demographic profiles and represented 18 different courses aimed at nonmajors and lower- and upper-division biology majors. Results revealed construal-consistent language in all 90 sampled classes. Anthropic language was more frequent than teleological or essentialist language, and frequency of construal-consistent language was surprisingly consistent across instructor and course level. Moreover, results were surprisingly consistent across the two universities. These findings suggest that construal-consistent language is pervasive in the undergraduate classroom and highlight the need to understand how such language may facilitate and/or interfere with students learning biological science.
\end{abstract}

\section{INTRODUCTION}

For the vast majority of our existence as a species, intuitive biological thinking has likely allowed us to classify, explain, and predict the behavior of plants and animals that we depended on for survival (Medin and Atran, 2004). Despite its usefulness in everyday life, intuitive biology may give rise to systematic misconceptions among students studying the life sciences (see, e.g., Shtulman and Schulz, 2008; Nehm et al., 2010; Coley and Tanner, 2012, 2015; Kelemen, 2012). Although students likely enter classrooms with misconceptions associated with intuitive biological thinking, it is not clear whether they continue to encounter intuitive ideas in the context of college science. In particular, we know little about the degree to which intuitive ideas are represented in the primary source of formal scientific information for life sciences students: the input they receive from instructors in the college biology classroom. Thus, the current study investigates the extent to which language consistent with pervasive patterns of intuitive biological thinking — cognitive construals—is used by undergraduate biology instructors.

\section{Cognitive Construals}

A large body of research has examined intuitive biological thinking in children and adults and has identified several cognitive construals (see, e.g., Tamir and Zohar, 1991; Gelman, 2003; Coley, 2007; Coley and Tanner, 2012; Kelemen and Rosset, 2009)
Ross Nehm, Monitoring Editor

Submitted Apr 19, 2019; Revised Aug 20, 2019; Accepted Sep 20, 2019

CBE Life Sci Educ December 1, 2019 18:ar63

DOI:10.1187/cbe.19-04-0076

*Address correspondence to: Nicole Betz (betz.nicolejoy@gmail.com).

(c) 2019 N. Betz et al. CBE-Life Sciences Education () 2019 The American Society for Cell Biology. This article is distributed by The American Society for Cell Biology under license from the author(s). It is available to the public under an Attribution-Noncommercial-Share Alike 3.0 Unported Creative Commons License (http:// creativecommons.org/licenses/by-nc-sa/3.0)

"ASCB®" and "The American Society for Cell Biology ${ }^{\circledR}$ " are registered trademarks of The American Society for Cell Biology. 
that people may spontaneously use when reasoning about biological concepts. Some of the cognitive construals that have been most studied in the context of biology include anthropic thinking (which we have previously called "anthropocentric thinking," as explained later), essentialist thinking, and teleological thinking. Previous studies have suggested that these cognitive construals persist despite formal scientific education (Goldberg and Thompson-Schill, 2009; Shtulman and Valcarcel, 2012; Kelemen et al., 2013; Coley and Tanner, 2015), and these construals have been linked to biological misconceptions (see, e.g., Shtulman, 2006; Kelemen, 2012; Coley and Tanner, 2015; Richard et al., 2017; Stern et al., 2018), although construal-consistent thinking is not necessarily incorrect, and indeed serves an important heuristic function (e.g., Blancke and De Smedt, 2013). Further, construals have also been seen as potentially useful pedagogical strategies for teaching biology (e.g., Zohar and Ginossar, 1998; Evans and Rosengren, 2018; for a review, see Geelan, 2012).

Anthropic Thinking. Anthropic thinking can involve 1) attributing human characteristics to nonhuman or inanimate objects, 2) using humans as a default analogical base for reasoning about biological species or processes, or 3) considering humans to be unique and biologically discontinuous with the rest of the animal world. United by the common theme of anchoring our understanding about the biological world in human terms, anthropic thinking is composed of two broad subtypes: anthropomorphic thinking and anthropocentric thinking. Anthropomorphic thinking refers to the attribution of human characteristics, qualities, or behaviors to nonhuman entities (see, e.g., Piaget, 1929; Tamir and Zohar, 1991; Kallery and Psillos, 2004). In contrast, anthropocentric thinking is the disproportionate emphasis of humans above other living things. Anthropocentrism suggests that humans are biologically privileged or unique; this results in the distortion (i.e., overemphasis) of the place of humans in the world. This could manifest as thinking about humans as exceptional to other species (i.e., Coley, 2007; Pickering, 2008; Gee, 2013) or using human examples (Nettle, 2010; Pobiner, 2016) or analogies to man-made objects when teaching biology. Although we have considered these subtypes under the single umbrella of "anthropocentric thinking" in our previous work, we acknowledge that it is important to also distinguish between these subtypes, because they are conceptually distinct and therefore might differentially impact learning outcomes (see also Byrne et al., 2009; Quinn et al., 2016).

Essentialist Thinking. Essentialist thinking is the assumption that concepts are based around an unobservable essential property (an "underlying reality" or "true nature") that conveys category identity and causes observable similarities among category members (Medin and Ortony, 1989; Ahn et al., 2001; Gelman, 2003). Because it may often be implicit, researchers have identified a number of more overt manifestations of essentialist thinking. We focus on a subset of such manifestations likely to be relevant to misconceptions among biology students (Gelman and Rhodes, 2012): underlying cause, homogeneity, and boundary intensification. Underlying cause refers to the notion that a superficial, observable property (e.g., albinism) is caused by an underlying, unobservable trait (e.g., a gene; see Rehder and Burnett, 2005). Homogeneity refers to the belief that members of a specific category (e.g., dogs) are uniform with respect to a specific property (e.g., barking), potentially exaggerating within-group similarity at the expense of variability. Boundary intensification emphasizes differences between groups, rather than similarities within them (Gelman, 2003; Gelman and Rhodes, 2012), and as such is related to but distinct from homogeneity. By reifying a category boundary, one creates a perception of two dichotomous groups, divergent from one another and homogenous within themselves. There are other manifestations of essentialist thinking beyond underlying cause, homogeneity, and boundary intensification (e.g., inductive potential, immutability). However, we focus on a subset we deemed most likely to appear in instructor language.

Teleological Thinking. Teleological thinking is causal reasoning in which a goal, purpose, function, or outcome of an event is taken as the cause of that event (e.g., giraffes evolved to have long necks in order to reach leaves on higher trees; see Keil, 2006; Kelemen and Rosset, 2009; Kampourakis, 2014). In contrast to the anthropomorphic thinking discussed earlier, teleological thinking does not require attribution of sentience or agency. Instead, a goal, purpose or function could be seen as the cause of an event without intentional goal-oriented actions. For example, students may erroneously think that a giraffe's need for a longer neck spurred a genetic mutation for this neck; such thinking is not anthropomorphic because the giraffe did not intentionally create this mutation (for this reason, other researchers have discussed an intentionality bias distinctly from a teleological bias; see, e.g., Evans, 2008; Sinatra et al., 2008).

\section{Effects of Cognitive Construals on Scientific Understanding}

Although cognitive construals serve as useful heuristics in many everyday contexts, in the case of formal science education, they may impede scientific understanding and have been associated with systematic misconceptions. For example, use of construal-consistent language in an open-ended written assessment was positively related to agreement with construal-consistent misconceptions across a broad range of biological content (Coley and Tanner, 2015). Richard and colleagues (2017) replicated this finding with a focus on the domain of antibiotic resistance. Further, Coley and colleagues (2017b) found that agreement with construal-consistent misconceptions was specifically and systematically linked to performance on standardized measures of construal-consistent thinking. For example, participants who more readily agreed with essentialist misconception statements also scored higher on measures of essentialist thinking, but not necessarily on measures of teleological or anthropic thinking. Other work has demonstrated relationships between specific construal-consistent thinking and biological misconceptions, including teleological thinking (e.g., Bishop and Anderson, 1990; Kelemen and Rosset, 2009; Nehm and Ridgway, 2011; Kampourakis, 2014), essentialist thinking (e.g., Shtulman and Schulz, 2008), and anthropic thinking (e.g., Moore et al., 2002; Shtulman, 2006; Byrne et al., 2009). Together, these studies demonstrate systematic relations between construal-consistent thinking and biological misconceptions.

Moreover, prior research has suggested that formal education may inhibit, but not eliminate, construal-consistent thinking. Not only are college students more likely to display construal-consistent thinking under speeded versus delayed task 
conditions (essentialism: Eidson and Coley, 2014; teleology: Keleman and Rosset, 2009; anthropocentrism: Goldberg and Thompson-Schill, 2009; Arenson and Coley, 2018) but even PhD-level scientists show signs of persistent construal-consistent thinking when tested under time pressure. For example, Goldberg and Thompson-Schill (2009) found that biology professors-like undergraduate students-are slower and less accurate to confirm that plants are living things than to confirm that animals are living things, indicating underlying anthropocentric thinking. Similarly, Kelemen et al. (2013) demonstrated that physical scientists under time pressure endorsed the same scientifically incorrect teleological statements as nonexperts. Talanquer (2013) showed that teleological explanations for chemical processes were preferred over explanations involving mechanical causality, even among incoming graduate students. These and other studies (e.g, Shtulman and Valcarcel, 2012; Shtulman and Harrington, 2016) suggest that construal-consistent thinking is pervasive and may continue to coexist alongside more formal scientific understandings, even in advanced experts (see Shtulman and Lombrozo, 2016).

It is critical to emphasize that, although construal-consistent thinking can contribute to misconceptions, the two are by no means synonymous. First of all, many commonly held student misunderstandings may stem from sources other than intuitive systems of thought, such as factual errors. More importantly, construal-based thinking can be consistent with scientific knowledge; indeed, systems of intuitive thinking that were antithetical to reality would not be particularly useful. For example, humans do have some exceptional qualities (to our knowledge, no other species builds highways, writes papers on intuitive thinking, or has brought about a global climate crisis). But overextending beliefs about human exceptionalism can lead to systematic misconceptions, such as the belief that humans are the "most highly evolved" or complex species. The essentialist idea that underlying unobservable properties cause surface features is a critical component of genetics, but oversimplification of this idea can lead to essentialist beliefs about genetic determinism (e.g., Dar-Nimrod and Heine, 2011). Likewise, another consequence of essentialist thinking is belief in the homogeneity of category members, and members of a species do share many important features. Indeed, understanding of shared properties supports a critical feature of scientific inquiry: generalization. However, assumptions of category homogeneity can also lead to systematic discounting of within-species variability, a critical component of understanding evolution (e.g., Shtulman and Schulz, 2008; Coley and Muratore, 2012; Gelman and Rhodes, 2012).

Teleological thinking may be the best example of the utility of cognitive construals and limits thereof. On one hand, biological features have consequences, and selection pressure acts on these; for example, one popular hypothesis is that proto-giraffes with longer necks left more offspring because they were able to forage more successfully. Philosophers of science have long argued that such construal-consistent teleological explanations are legitimate (e.g., Brandon, 1981), and teleological explanations have had a pivotal role in science history (Lennox and Kampourakis, 2013). For example, Lennox (1993) argued that Darwinian evolution is teleological. Although Darwin's use of teleology does not necessarily include conscious design, it provides functional explanations for adaptation and selection, resulting in "predictive fertility" (Ruse, 2000, p. 231). Although a detailed consideration of teleological thinking in the history and philosophy of biology is beyond the scope of this article (see Mayr, 1982; Kelemen, 2012; Lennox and Kampourakis, 2013), the points to emphasize are that considering the importance of function per se does not necessarily lead to misconceptions. Rather, teleological thinking about biology can foster misconceptions by creating a false impression that the purpose or function of an event came to exist in the service of the event's antecedent (e.g., that the need to reach higher trees spurred the development of longer necks in giraffes; this perception of need-based evolution was observed in undergraduates, e.g., Nehm and Ridgway, 2011). Systematic misconceptions arise when the function of a biological trait is seen as the cause of the trait. More generally, while construal-based thinking is not necessarily incorrect, it has the potential to create incorrect scientific understandings. Our previous research highlights the prevalence of this consequence (e.g., Coley and Tanner, 2015; Coley et al., 2017b; Richard et al., 2017).

\section{Presence of Cognitive Construals in Formal Science Education}

Whether an instructor is giving a traditional lecture or incorporating more active-learning strategies, the content presented in classrooms serves as the primary source of course-relevant information for students. A central feature of biology classrooms is instructors' biological language, or orally presented biological content during formal class time. It is therefore important to look at whether instructors use common patterns of language when describing biology, particularly language that could potentially interact with the ideas and cognitive frameworks that students have been shown to bring with them into the classroom. Although looking at the content of instructor's language itself does not provide information about other important dimensions such as the instructor's intended meaning or students' interpretations (for a review, see Rector et al., 2013), we see it as an important first step in characterizing the authentic educational environment in which students learn biology.

We have argued that cognitive construals are pervasive in informal reasoning, resistant to change, and linked to systematic misconceptions in biological science. One possible explanation for the persistence of construal-consistent misconceptions is the presence of construal-consistent language in formal scientific discourse. For instance, Talanquer (2007) documented teleological explanations in chemistry textbooks and argued that generalizations of such explanations could lead to teleological misconceptions (although, see Zohar and Ginossar, 1998). Although it is unlikely that college-level biology instructors explicitly hold construal-consistent misconceptions (see, e.g., Nehm and Ridgway, 2011; Ha and Nehm, 2014; Richard et al., 2017; Fux et al., 2018), the persistence of implicit construalconsistent thinking among expert scientists raises the possibility that instructors might use such language-intentionally or unintentionally-in the science classroom. Exposure to such construal-consistent language may thereby reify existing construal-consistent misconceptions, either by confirming students' construal-consistent but mistaken understandings or by failing to contradict or challenge construal-consistent misconceptions. 
Indeed, some instructors might intentionally use construal-consistent language in the classroom to simplify concepts, or to make the material more engaging to students. A growing body of research suggests that the strategic use of construal-consistent language could serve as a useful pedagogical tool. For example, Treagust and Harrison (2000) argued that anthropomorphic and teleological analogies could elucidate abstract concepts when teaching physics. Further, Talanquer (2007) posits that teleological explanations in chemistry education could serve to justify why chemicals are structured or processed in particular ways, which can help students organize and simplify their understandings of otherwise complicated processes. Further, Zohar and Ginossar (1998) found that the majority of sampled high school students reported that anthropomorphic and teleological language in biology textbooks enhanced their understanding and interest in the subject. Because of these types of benefits to students, some researchers argue for the use of anthropomorphic and teleological language if used judiciously (see, e.g., Zohar and Ginossar, 1998; for a review, see Geelan, 2012).

Although instructors' construal-consistent language might have the potential to both reinforce construal-consistent misconceptions about biology and serve as a pedagogical tool in science education, little research has investigated whether instructors use construal-consistent language in the biology classroom, and the handful of studies largely focus on high school settings. These studies have demonstrated that high school teachers use teleological language when teaching biology (see, e.g., Nehm and Schonfeld, 2007; Gresch and Martens, 2019). The use of cognitive construals in undergraduate biology classrooms and the prevalence of anthropic and essentialist language in biology classrooms remain underinvestigated.

\section{The Current Research}

Our goal in this study was to investigate the presence of construal-consistent instructor language at different points in the undergraduate biology curriculum to better describe the undergraduate educational environment. Characterizing the information available in students' learning environments will serve as a first step toward determining whether construal-consistent biological misconceptions stem solely from intuitive beliefs that students bring with them to the classroom, or whether they could also be induced or reinforced by instructor language. Research questions included 1) Do university biology instructors use construal-consistent language in general? 2) To what extent does construal-consistent language vary by a) instructor or b) intended class audience? 3) Are particular types of construal-consistent language more or less prevalent? 4) To what extent do particular types of construal-consistent language vary by a) instructor or b) intended class audience?

We were also interested in the degree to which any patterns we might discover generalized to different kinds of institutions, or whether patterns of instructor language might be more idiosyncratic to individual institutions (or instructors). To address this question, we investigated instructor language at two contrasting institutions (both in the United States): a large public university on the West Coast and a large private university on the East Coast. We refer to these as University 1 and University 2 , respectively. Our aim is not to make direct quantitative comparisons between universities, but rather to ascertain whether similar qualitative patterns hold for both universities.

\section{METHODS}

\section{University Demographics}

University 1, a large urban public university on the West Coast, has $\sim 27,000$ undergraduate students. University 2, a large urban private university on the East Coast, has $\sim 18,000$ undergraduate students. Based on student demographics (Table 1), University 1 has a more diverse student body (larger proportions of Hispanic, Asian, and Black students), whereas University 2 has a less diverse student body as well as higher Scholastic Aptitude Test (SAT) scores and grade point average (GPA) of incoming students. In other words, Universities 1 and 2 present strikingly different demographic profiles.

\section{Courses Analyzed}

At each university, we collected recordings of 45 different class meetings, for a total sample of 90 recorded classes. These consisted of five classes from each of nine biology courses (three lower-division courses for nonmajors, three lower-division courses for biology majors, and three upper-division courses for biology majors) at each university. Each course had a different instructor (though the content of each course was not necessarily unique). All recordings were professionally transcribed. The type of speaker (i.e., instructor or student) was noted each time the speaker changed. Classes at University 1 ranged in length from 40 to 90 minutes (mean 52.3 minutes); classes at University 2 ranged in length from 41 to 109 minutes (mean 77.3 minutes).

\section{Coding Instructor Language}

Description and Rationale of Time-Sampling Methodology. Spoken language is full of false starts, run-on sentences, and changes of direction, and does not easily resolve into discrete units like written language, with its orderly sentences and periods. Nor do biology classes contain natural breaks dividing them into subunits. Therefore, we chose to use a time-sampling methodology (Zhang and Wildemuth, 2009) and divided each class transcript into 1-minute time segments that became our coding units. While other time-sampling studies of instructional language used longer time segments (e.g., 5- to 10-minute segments; see Gest et al., 2006), we chose 1 minute as our segment length, because it allowed for a sufficient amount of content while still providing a relatively fine-grained analyses

TABLE 1. Demographic information for Universities 1 and $2^{\text {a }}$

\begin{tabular}{lcc}
\hline Demographic category & University 1 & University 2 \\
\hline Hispanic/Latinx & $30.5 \%$ & $7.0 \%$ \\
Asian & $27.4 \%$ & $12.6 \%$ \\
White & $18.9 \%$ & $46.3 \%$ \\
International & $7.1 \%$ & $20.4 \%$ \\
Black/African American & $5.0 \%$ & $3.9 \%$ \\
Native Hawaiian/Pacific Islander & $0.5 \%$ & $0.0 \%$ \\
American Indian/Alaskan Native & $0.2 \%$ & $0.1 \%$ \\
Ethnicity unknown & $10.5 \%$ & $9.7 \%$ \\
Women & $55.8 \%$ & $50.7 \%$ \\
Mean SAT score & 1050 & 1445 \\
Mean high school GPA & 3.2 & 4.0 \\
\hline
\end{tabular}

aDemographic information downloaded from College Factual (www.collegefactual .com/colleges) on February 26, 2019. 
of class time (i.e., a reasonable number of coding segments per class). Segmentation was done in tandem with transcription.

Coding Procedure. Three trained researchers coded the transcripts for content. Each class transcript was coded by two coders. Coding was carried out in three phases. For consistency, a primary coder (N.B.) coded all the transcripts, and two secondary coders (J.S.L., E.E.D.T.) each coded roughly half of the transcripts for phase 1 and phase 2 and traded halves for phase 3 (see Coding for Construal-Consistent Language). Coding assignments were apportioned so that both secondary coders worked on classes from each target course during all phases. The coders made all coding decisions independently, and any discrepancies were discussed; in the rare event that the two coders could not reach consensus, the third coder was consulted to make the final coding decision.

Coding for Biological Content. During the first phase of coding, each minute of the transcript was coded for presence of biological content, defined as any use of biological terminology or attempts to convey biological concepts by the instructor. Interrater agreement was high (percentage agreement $=96 \%$ ). Minutes lacking biological content (e.g., reviewing due dates of upcoming homework assignments) were not examined further. Henceforth, we will refer to a 1-minute period of class time containing some biological content as a content minute.

Coding for Construal-Consistent Language. During phase 2, coders examined each segment for evidence of any language consistent with anthropic, essentialist, or teleological thinking. This was deductive coding based on previously established coding systems (Coley and Tanner, 2015; Richard et al., 2017; for definitions of codes, see Table 2; for sample codes, see Table 3). Under this system, each segment was coded for the presence or absence of each of the three types of construal-consistent language. These codes were not mutually exclusive. For example, explanations in which nonhuman entities intentionally adjust their behaviors to meet their needs in goal-directed ways would be coded for both anthropomorphism (because of the intentionality) and teleology (because the goal was driving the behav- ior). No specific language patterns were required for any of the three construals, although some common patterns emerged (e.g., many teleological codes included the phrase "in order to"). In an attempt to be conservative with this coding, we did not code formal biology terminology as construal-consistent (e.g., "sister chromatids," which could be seen as anthropic, because the concept "sisters" is typically reserved for human relationships). Interrater agreement across both pairs of coders was high during phase 2 (percentage agreement 82-86\%).

While carrying out phase 2 coding, coders noticed the presence of certain subtypes of essentialist and anthropic language in the transcripts. Based on these emergent observations, we created a set of theoretically interesting subtypes of anthropic and essentialist language that allowed us to make finer distinctions regarding the patterns of language observed in the sample. The majority of these observed subtypes aligned with ones previously observed in the literature reviewed in the Introduction (e.g., essentialism, Gelman, 2004; Gelman et al., 1994; anthropic, Byrne et al., 2009; Gee, 2013). For essentialist language, we distinguished between statements conveying homogeneity, underlying cause, and boundary intensification, three distinct consequences of essentialist thinking (see Tables 2 and 3). For anthropic language, we distinguished between language conveying anthropocentrism and language conveying anthropomorphism (see Tables 2 and 3). Within anthropocentric language, we further distinguished between the theoretically significant human exceptionalism, and two types of anthropocentric language that we consistently observed in the corpus, artifact analogy and human example (definitions and examples of each subtype are given in Tables 2 and 3, respectively).

During phase 3 , coders reviewed all content minutes identified as containing construal-consistent language in phase 2 with two purposes. The first was to code each segment previously identified as containing anthropic or essentialist language for evidence of the aforementioned construal subtypes. These were coded inductively, using a constant comparative method (Glaser and Strauss, 1967; Boeije, 2002). Phase 3 also provided an opportunity to review coding decisions from phase 2 to ensure accuracy and consistency across the entire data set.

TABLE 2. Coding criteria for anthropic, teleological, and essentialist language

\begin{tabular}{|c|c|c|}
\hline Construal & Subtypes & Description \\
\hline \multirow[t]{4}{*}{ Anthropic language } & Anthropomorphism & Assignment of human or animate characteristics to nonhuman organisms \\
\hline & Anthropocentrism & $\begin{array}{l}\text { Human Exceptionalism: Strong suggestion or explicit statement that humans are } \\
\text { exceptional to, or unique from, other species }\end{array}$ \\
\hline & & $\begin{array}{l}\text { Artifact Analogy: Explicit or implicit comparison of a biological process or entity to } \\
\text { human-made artifacts }\end{array}$ \\
\hline & & $\begin{array}{l}\text { Human Example: Use of humans or human activities to exemplify or elaborate on a } \\
\text { general topic within biology }\end{array}$ \\
\hline Teleological language & & $\begin{array}{l}\text { Statements in which a goal, purpose, or function is taken as the cause of an event or } \\
\text { process. }\end{array}$ \\
\hline \multirow[t]{3}{*}{ Essentialist language } & Homogeneity & $\begin{array}{l}\text { Explicit statement that members of a category are identical with respect to one or more } \\
\text { properties, behaviors, process, or other features }\end{array}$ \\
\hline & Boundary intensification & $\begin{array}{l}\text { Explicit mention of distinct subgroups, sharp/absolute boundaries between related } \\
\text { categories, or differentiation between superficially similar categories based on different } \\
\text { underlying properties }\end{array}$ \\
\hline & Underlying cause & $\begin{array}{l}\text { Explicit or strongly implied assertion that superficial properties or category memberships } \\
\text { are caused by some underlying causal principle or internal essence }\end{array}$ \\
\hline
\end{tabular}


TABLE 3. Examples of construal-consistent language from Universities 1 and 2

\begin{tabular}{|c|c|c|c|}
\hline Construal & Subtypes & Examples from University 1 & Examples from University 2 \\
\hline \multirow{10}{*}{$\begin{array}{l}\text { Anthropic } \\
\text { language }\end{array}$} & \multirow[t]{2}{*}{ Anthropomorphism } & Cells want to talk to one another. & Their body says, "Oh, we've got to put on weight." \\
\hline & & $\begin{array}{l}\text { These white blood cells sneak out to eat up } \\
\text { the bacteria. }\end{array}$ & $\begin{array}{l}\text { The inhibitor tricks the cell into thinking that there's } \\
\text { an energy crisis }\end{array}$ \\
\hline & \multirow{2}{*}{$\begin{array}{r}\text { Anthropocentrism: } \\
\text { Human } \\
\text { exceptionalism }\end{array}$} & Only humans can get this infection. & \multirow[b]{2}{*}{$\begin{array}{l}\text { The human brain has special properties that other } \\
\text { species do not have. } \\
\text { Human speech is so complex that it can't be compared } \\
\text { to bird vocalizations, or most other vocalizations } \\
\text { in general. }\end{array}$} \\
\hline & & $\begin{array}{l}\text { Animals couldn't disperse something as large } \\
\text { as a coconut, only humans could do } \\
\text { something like that. }\end{array}$ & \\
\hline & Anthropocentrism: & DNA replication is like a copy machine. & We can think about an axon's passive properties \\
\hline & Artifact analogy & $\begin{array}{l}\text { MHC is the bun, and then the antigen is the } \\
\text { hot dog. }\end{array}$ & $\begin{array}{l}\text { similar to how we would think in terms of a } \\
\text { battery. }\end{array}$ \\
\hline & & & $\begin{array}{l}\text { If we look at the Earth's surface, it looks kind of like } \\
\text { the surface of a baseball. }\end{array}$ \\
\hline & \multirow{5}{*}{$\begin{array}{l}\text { Anthropocentrism: } \\
\text { Human example }\end{array}$} & Human brains use ATP to function properly. & Like humans and most other terrestrial animals, most \\
\hline & & Runners build up lactic acid in their muscles & species of fishes do have two sexes. \\
\hline & & during aerobic workout & $\begin{array}{l}\text { Every time that I think about the lysosomes I think } \\
\text { about Brad Marchand. }\end{array}$ \\
\hline \multirow[t]{2}{*}{$\begin{array}{l}\text { Teleological } \\
\text { language }\end{array}$} & & $\begin{array}{l}\text { Cacti have spikes in order to ward off their } \\
\text { predators. }\end{array}$ & $\begin{array}{l}\text { The ligand alters the response so that the receptor } \\
\text { becomes activated. }\end{array}$ \\
\hline & & $\begin{array}{l}\text { The bases, which are hydrophobic, are going } \\
\text { to interact more closely in order to avoid } \\
\text { the water. }\end{array}$ & $\begin{array}{l}\text { And this is all going to happen in order to cause } \\
\text { vasoconstriction. }\end{array}$ \\
\hline \multirow{6}{*}{$\begin{array}{l}\text { Essentialist } \\
\text { language }\end{array}$} & \multirow[t]{2}{*}{ Homogeneity } & All plants contain chloroplasts. & \multirow{2}{*}{$\begin{array}{l}\text { The first amino acid translated for every polypeptide } \\
\text { will always be methionine. } \\
\text { PAMPs are found on all pathogens. }\end{array}$} \\
\hline & & If it's a mammal, it has a placenta. & \\
\hline & \multirow[t]{2}{*}{$\begin{array}{r}\text { Boundary } \\
\text { intensification }\end{array}$} & $\begin{array}{l}\text { So the xylem's always inside, the phloem's } \\
\text { always outside. } \\
\text { Even though the two animals look similar }\end{array}$ & \multirow{2}{*}{$\begin{array}{l}\text { These non-HDL cholesterols can feed a lesion and } \\
\text { deposit lots of lipid there. Whereas, the HDL can } \\
\text { actually do the opposite. } \\
\text { Increasingly, over age and time, male squirrels go } \\
\text { farther and farther away from their birth burrow. } \\
\text { The females stay nearby. }\end{array}$} \\
\hline & & $\begin{array}{l}\text { they are different organisms because they } \\
\text { have different DNA. }\end{array}$ & \\
\hline & \multirow[t]{2}{*}{ Underlying cause } & This gene is responsible for albinism. & The parasite that causes malaria... \\
\hline & & $\begin{array}{l}\text { Without this protein, the organism would } \\
\text { have no hair. }\end{array}$ & $\begin{array}{l}\text { DNA, okay, is what specifies what your cells are going } \\
\text { to become. }\end{array}$ \\
\hline
\end{tabular}

Italics emphasize content from examples that led coders to these decisions.

\section{Scoring}

There were 2059 content minutes in which instructors discussed biological content in the sample from University 1 , and 2813 content minutes in the sample from University 2 . We used the class (i.e., one class meeting of a course) as our unit of analysis. On this metric, percentage of class minutes containing biological content ranged from 58 to $100 \%$, with a mean of $87 \%$, at University 1 , and from 34 to $100 \%$, with a mean of $81 \%$, at University 2 . For each of these content minutes, we assigned a value of " 1 " for each type of construal-consistent language that was present and a value of " 0 " for each type of construal-consistent language that was absent (for both phase 2 and phase 3 codes). To investigate whether construal-consistent language was present at all across sampled classes, we first calculated the percentage of content minutes per class session at each university containing any type of construal-consistent language. To make finer comparisons about variations in use of construal-consistent language, we also calculated the percentage of content minutes per class session that contained each type of construal-consistent language (i.e., anthropic, teleological, and essentialist language) for each individual class. Percentages were used because class sessions varied in the number of content minutes they contained. Thus, each class session received a score ranging from 0 to $100 \%$ that reflected the percentage of minute-long biologically relevant segments in which each type of construal-consistent language was present.

\section{Statistical Analysis}

Except where cases noted, analyses were conducted separately for the two universities. To compare frequency of each type of construal-consistent language, and frequency of use in courses aimed at different student audiences, we conducted course audience (lower-division majors, lower-division majors, upper-division majors) $\times$ construal type mixed analyses of variance (ANOVAs) with repeated measures on construal type for both phase 2 general types (anthropic, essentialism, teleology) and thereafter for phase 3 subtypes. For phase 3 subtypes, categories of construal type varied by analysis due to different numbers of subtypes for each construal. To compare frequency of construal-consistent language across instructors, we conducted one-way factorial ANOVAs. Follow-up tests were conducted using Bonferroni-corrected paired-sample $t$ tests (for within-subjects comparisons) or Tukey honestly 
significant difference (HSD) tests (for between-subject comparisons). All ANOVAs used class session as the unit of analysis. In cases in which we observed discrepant patterns of results from Universities 1 and 2, we conducted additional ANOVAs on the combined data set with university as an additional independent variable to assess whether patterns held across instructors for both universities. In such cases, a further interaction with university would be evidence for genuine differences, whereas the lack of such an interaction would indicate a single pattern across both universities.

\section{RESULTS}

We organized the results to address our research questions. 1) Do university biology instructors use construal-consistent language in general? 2) To what extent does construal-consistent language vary by a) instructor or b) intended class audience? 3) Are particular types of construal-consistent language more or less prevalent? 4) To what extent do particular types of construal-consistent language vary by a) instructor or b) intended class audience?

\section{Research Question 1: Do University Biology Instructors Use Construal-Consistent Language in General?}

Construal-consistent language was commonly used by undergraduate biology instructors and was evident in all classes analyzed at both universities. At University 1 , the percentage of content minutes per class session with construal-consistent language ranged from 16 to $74 \%$, with a mean of $43 \%$. At University 2 , percentages ranged from 35 to $97 \%$, with a mean of $60 \%$. This difference was statistically significant, $t(88)=5.76$, $p<0.001$, Cohen's $d=1.21$.

\section{Research Question 2a: To What Extent Does}

Construal-Consistent Language Vary by Instructor?

Instructors at each university were surprisingly similar in their average overall use of construal-consistent language. ANOVA revealed no significant differences between instructors in mean percentage of content minutes containing construal-consistent language at University $1(F(8,36)=0.98, p=$ 0.467 ; see Figure $1 \mathrm{~A})$ or University $2(F(8,36)=1.19, p=$ 0.332; see Figure 1B).

\section{A. University 1}

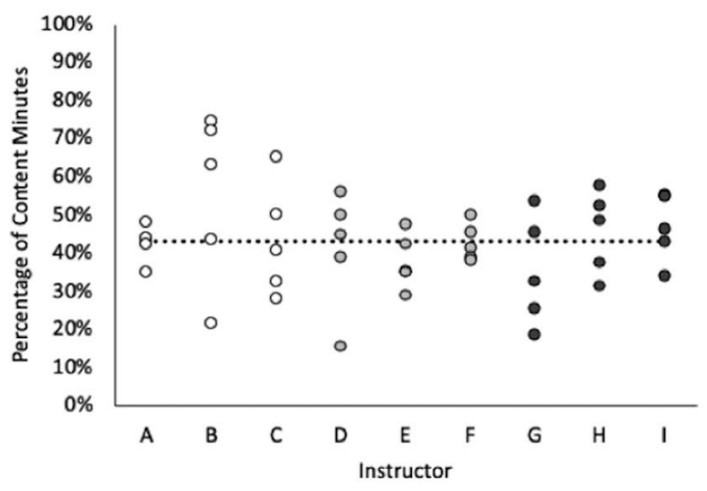

Research Question 2b: To What Extent Does Use of Construal-Consistent Language Vary by Intended Course Audience?

Likewise, instructors did not differ in their use of construal-consistent language for courses aimed at different audiences. ANOVA revealed no significant differences in the general use of construal-consistent language for classes aimed at nonmajors, lower-division majors, or upper-division majors at University 1 $(F(2,42)=0.99, p=0.379$; see Figure $2 \mathrm{~A})$ or University 2 $(F(2,42)=0.09, p=0.916$; see Figure $2 \mathrm{~B})$.

\section{Research Question 3: Are Particular Types of Constru- al-Consistent Language More or Less Prevalent?}

At University 1, anthropic language was used in 100\% of classes, teleological language was present in $98 \%$ of classes, and essentialist language appeared in $84 \%$ percent of classes. At University 2, anthropic language was used in $100 \%$ of classes, whereas teleological and essentialist language were both present in $96 \%$ of classes. ANOVA revealed that anthropic language was present in a higher percentage of content minutes per class session than teleological or essentialist language, which did not differ from each other. This pattern held at both University 1 $\left(F(2,88)=112.14, p<0.001, \eta^{2}=0.72\right.$; see Figure $\left.3 \mathrm{~A}\right)$ and University $2\left(F(2,88)=145.72, p<0.001, \eta^{2}=0.78\right.$; see Figure $3 \mathrm{~B}$; Bonferroni-corrected pairwise comparisons $p<0.001$ ).

\section{Research Question 4a: To What Extent Do Particular Types} of Construal-Consistent Language Vary by Instructor?

As can be seen in Figure 4, instructors were again remarkably similar in their average use of each type of construal-consistent language.

Anthropic Language. Percentage of content minutes per class session containing anthropic language ranged from 4 to $49 \%$ at University 1 and from 18 to $97 \%$ at University 2 . In other words, every instructor used anthropic language in every class. Oneway ANOVA revealed no significant differences among instructors in the mean percentage of content minutes per class session containing anthropic language at University $1(F(8,36)=1.45$, $p=0.210$; Figure $4 \mathrm{~A})$ or University $2(F(8,36)=1.71, p=0.129$; Figure 4B).

\section{B. University 2}

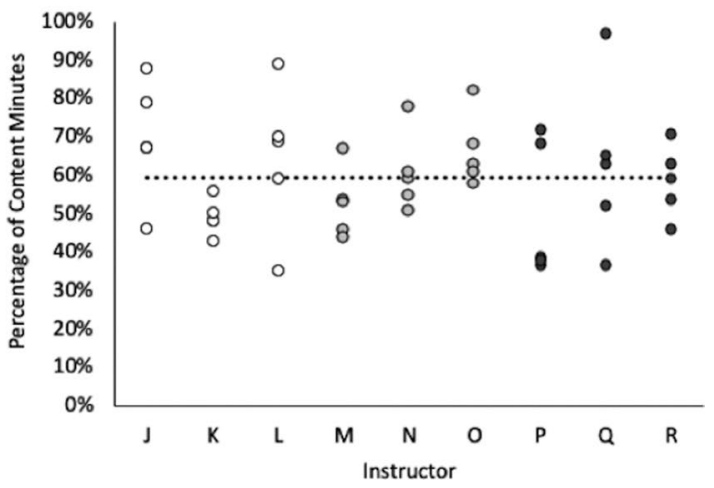

FIGURE 1. Percentage of content minutes containing any construal-consistent language for each class and each instructor for University 1 (A) and University 2 (B). Note: each dot represents one class session, dotted line represents grand mean for each university. Fill shading represents class level: white, nonmajor classes; gray, lower-division major classes; black, upper-division major classes. 


\section{A. University 1}

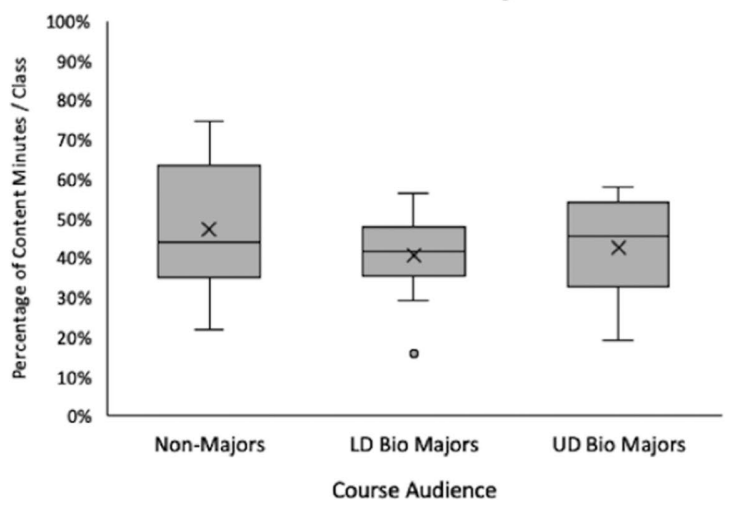

B. University 2

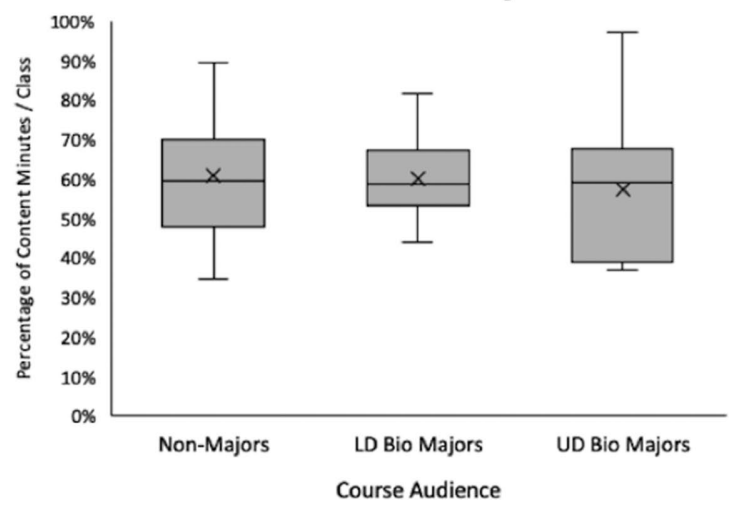

FIGURE 2. Percentage of content minutes per class session containing any construal-consistent language for courses aimed at nonmajors, lower-division (LD) biology majors, and upper-division (UD) biology majors for University 1 (A) and University 2 (B). Note: For all box plots presented here, the " $X$ " represents the mean score, the crossbar represents the median score, the shaded rectangle represents the middle quartiles, the whiskers represent the range of data points observed, and points outside the whiskers represent statistical outliers.

Teleological Language. Percentage of content minutes per class session containing teleological language ranged from 0 to $27 \%$ at University 1 (Figure 4C), where eight of nine instructors used teleological language in all five sampled classes. At University 2 , percentage of content minutes containing teleological language ranged from 0 to 47\% (Figure 4D); again, eight of nine instructors used teleological language in all five sampled classes. Instructors did not differ significantly in their mean percentage of content minutes per class session containing teleological language at University $1(F(8,36)=1.92, p=0.087)$. In contrast, ANOVA revealed reliable differences among instructors in the mean percentage of content minutes per class session containing teleological language at University $2(F(8,36)=$ $\left.3.90, p=0.002, \eta^{2}=0.46\right)$. Specifically, Instructor $\mathrm{O}$ was an outlier in the use of teleological language $(\mathrm{M}=28.0 \%)$, and did so significantly more often than Instructors $\mathrm{M}(\mathrm{M}=10.1 \%), \mathrm{N}$ $(\mathrm{M}=3.2 \%)$, and $\mathrm{Q}(\mathrm{M}=5.2 \%)$, Tukey HSD $p<0.05$. No other differences reached significance.

Essentialist Language. Percentage of content minutes containing essentialist language ranged from 0 to $26 \%$ at University 1

\section{A. University 1}

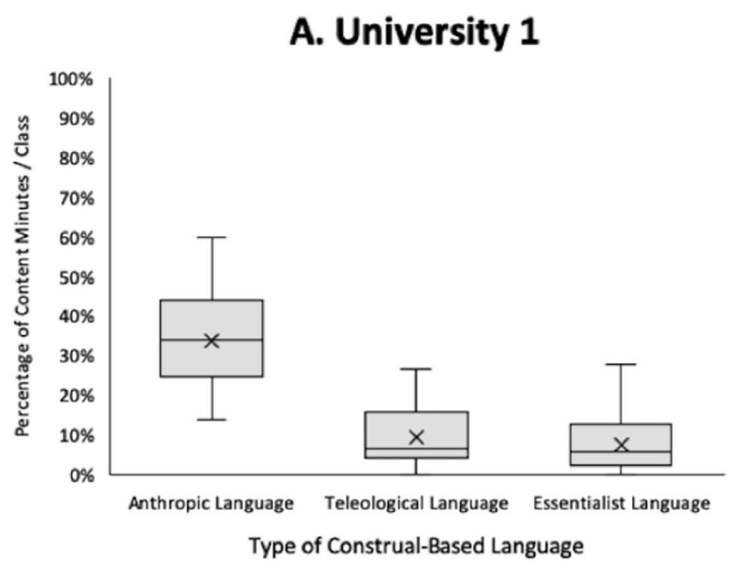

(Figure 4E), where five of nine instructors used essentialist language in all five classes. At University 2, percentage of content minutes containing essentialist language ranged from 0 to $50 \%$ (Figure 4F); seven of nine instructors at University 2 used essentialist language in all five sampled classes. Analyses revealed individual differences among instructors in the mean percentage of content minutes per class session containing essentialist language at both universities. At University 1 $\left(F(8,36)=2.44, p=0.032, \eta^{2}=0.35\right)$, post hoc tests revealed that Instructor E $(\mathrm{M}=15.1 \%)$ used essentialist language more than Instructor I $(M=0.9 \%$, Tukey HSD $p<0.05)$. At University $2\left(F(8,36)=6.00, p<0.001, \eta^{2}=0.57\right)$, Instructor $\mathrm{J}(\mathrm{M}=$ $30.6 \%)$ used essentialist language significantly more often than all other instructors except Instructor R $(\mathrm{M}=18.2 \%$, Tukey HSD $p<0.02)$.

\section{Research Question 4b: To What Extent Do Particular Types of Construal-Consistent Language Vary by Course Audience?}

Finally, we examined whether types (and where applicable, subtypes) of construal-consistent language differed for courses

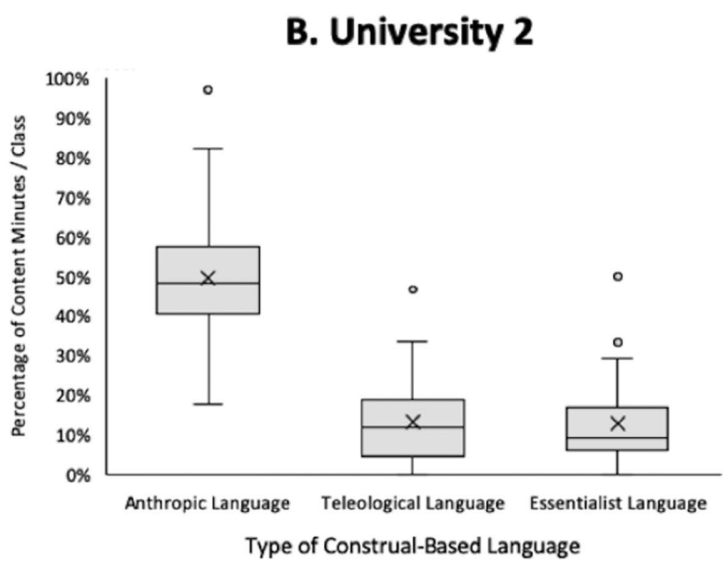

FIGURE 3. Mean percentage of content minutes per class session containing anthropic, teleological, and essentialist language for University 1 (A) and University 2 (B). 
A. Anthropic Construal-Consistent Language, University 1

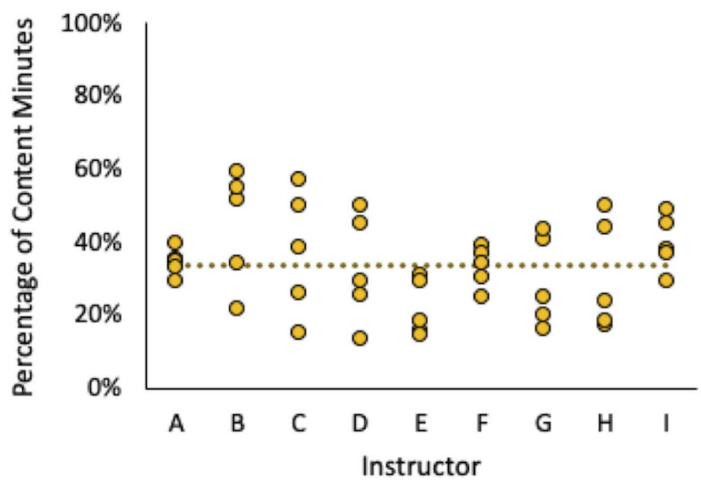

C. Teleological Construal-Consistent Language, University 1

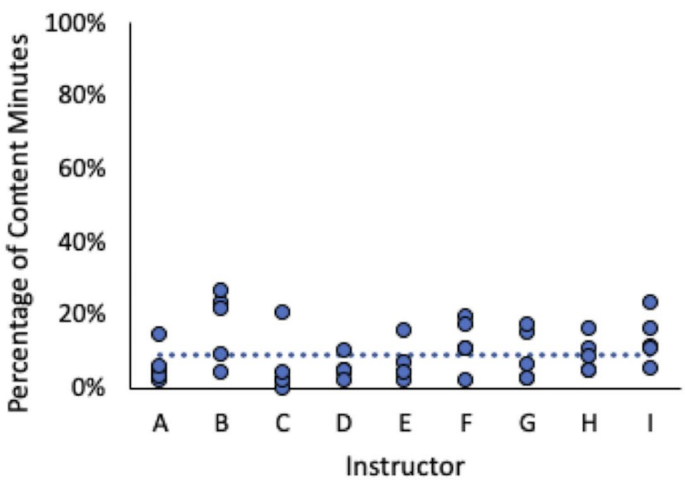

\section{E. Essentialist Construal-Consistent} Language, University 1

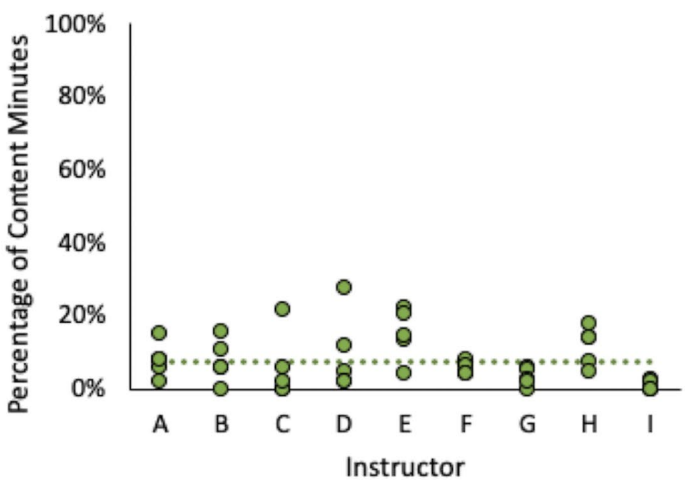

\section{B. Anthropic Construal-Consistent} Language, University 2

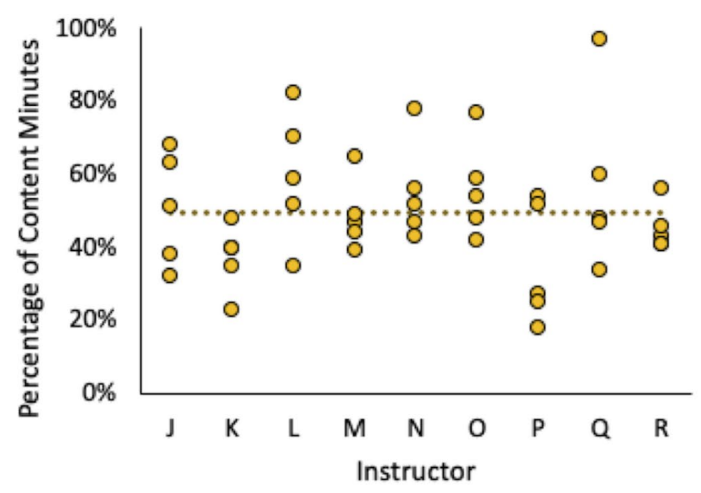

\section{Teleological Construal-Consistent} Language, University 2

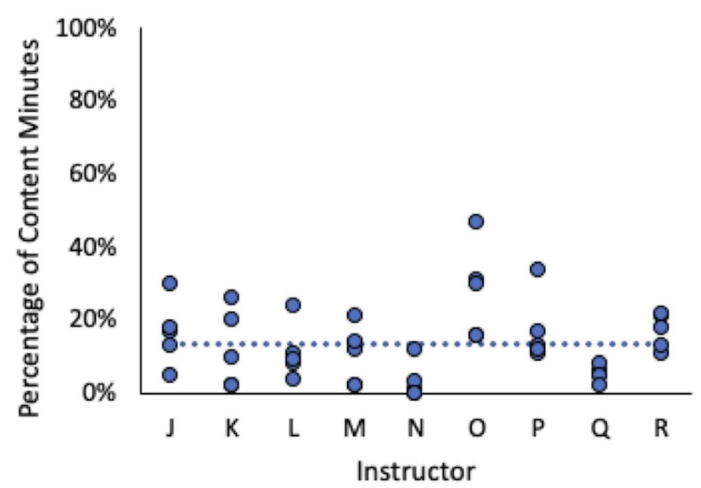

\section{F. Essentialist Construal-Consistent Language, University 2}

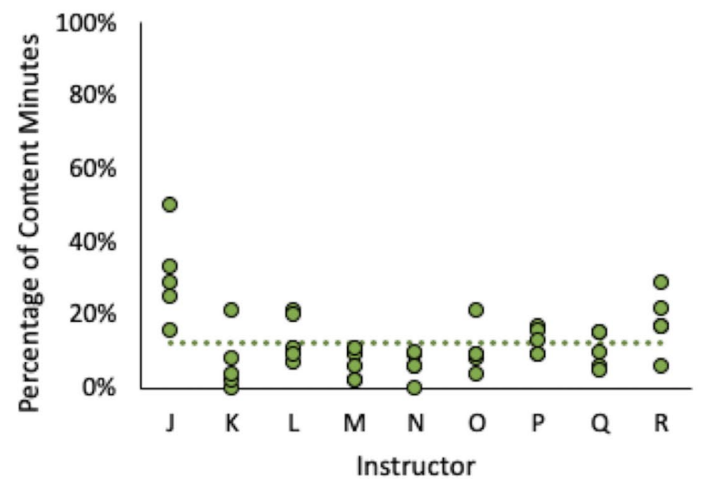

FIGURE 4. Percentage of content minutes containing anthropic (A, B), teleological (C, D), and essentialist (E, F) construal-consistent language for each class and each instructor. Note: dotted line represents grand mean.

aimed at nonmajors, lower-division biology majors, or upper-division biology majors.

Anthropocentric and Anthropomorphic Language. Recall that anthropic language could either be anthropomorphic or anthropocentric (see Table 1). Analysis suggested that, at University 1 , overall percentage of content minutes per class session containing anthropic language did not differ by course audience, $F(2,42)=1.79, p=0.180$. However, instructors showed distinct patterns of anthropomorphic and anthropocentric language use across class levels (anthropic subtype $\times$ course audience interaction, $F(2,42)=7.59, p=0.002, \eta^{2}=0.26$; see Figure 5A). A follow-up one-way ANOVA revealed that the percentage of content minutes per class session containing anthropocentric 

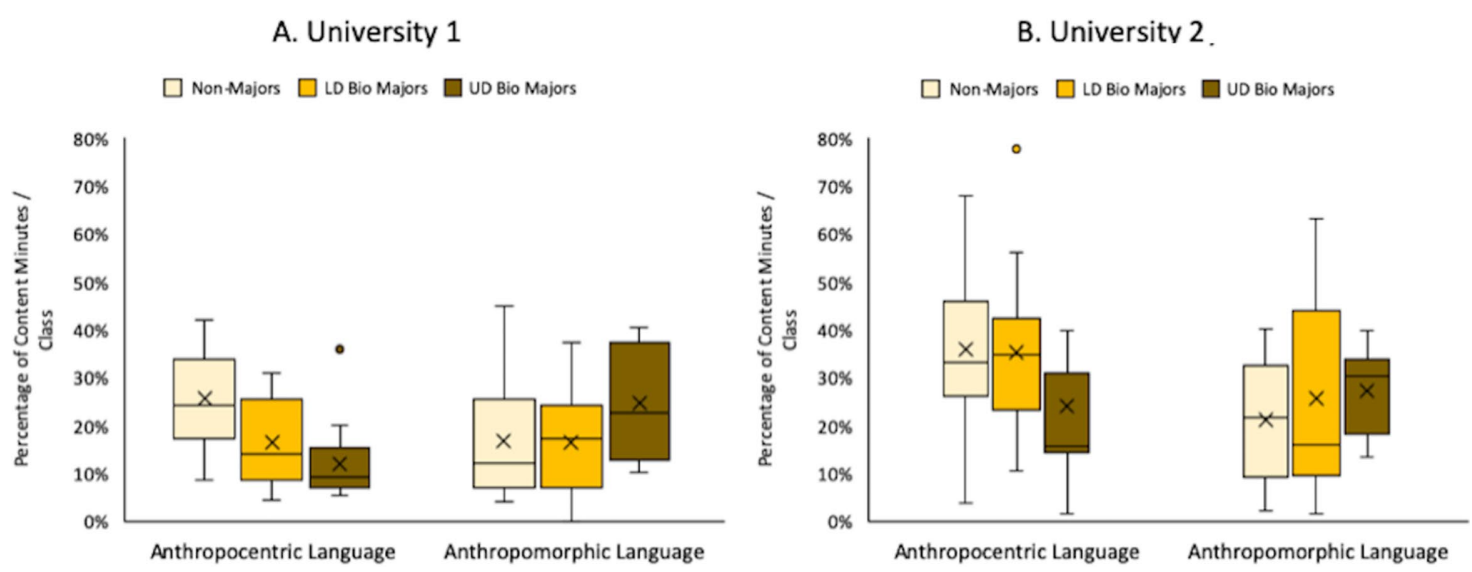

FIGURE 5. Mean percentage of content minutes containing anthropomorphic and anthropocentric language per class session for courses targeted at nonmajors, lower-division (LD) biology majors, and upper-division (UD) biology majors at University 1 (A) and University 2 (B).

language was higher in courses aimed at nonmajors than in courses aimed at lower- or upper-division biology majors, which did not differ $\left(F(2,42)=9.51, p<0.001, \eta^{2}=0.31\right.$, Tukey HSD $p<0.05)$. In contrast, anthropomorphic language did not differ by course audience $(F(2,42)=2.35, p=0.108)$. At University 2 , overall anthropic language also did not differ by course audience, $F(2,42)=0.84, p=0.437$. Although the qualitative patterns were similar to those seen at University 1 (see Figure 5B), the anthropic subtype $\times$ course audience interaction did not reach statistical significance $(F(2,42)=1.65, p=0.205)$.

These findings raise the possibility that relations between class level and types of anthropic language are different among instructors at the two universities. To test this hypothesis, we conducted a 2 (anthropic language subtype) $\times 2$ (university) $\times$ 3 (course audience) ANOVA on combined data from both universities. Results suggest a common pattern across both universities (specifically, analysis revealed a significant anthropic subtype $\times$ course audience interaction $[F(2,84)=6.00, p=0.004$, $\left.\eta^{2}=0.13\right]$ that did not interact with university $[F(2,84)=0.08$, $p=0.926])$. Tukey HSD follow-up tests confirmed the patterns depicted in Figure 5; percentage of content minutes per class session containing anthropocentric language was higher in nonmajor courses than in upper-division majors courses ( $p=$ 0.010), whereas percentage of content minutes per class session containing anthropomorphic language was somewhat higher in upper-division majors courses than in nonmajor courses, although the difference did not reach conventional levels of significance $(p=0.114)$.

Types of Anthropocentric Language. We compared the percentage of content minutes per class session containing subtypes of anthropocentric language (human exceptionalism, artifact analogy, and human example) via one-way ANOVA. Among instructors at University 1 , human example $(\mathrm{M}=11.3 \%)$ was more frequent than artifact analogy $(M=6.7 \%)$, which in turn was more frequent than human exceptionalism, which almost never occurred $\left(\mathrm{M}=0.4 \% ; F(2,88)=27.39, p<0.001, \eta^{2}=\right.$ 0.38 , Bonferroni-adjusted $p<0.05)$. The pattern was the same for instructors at University 2; human example ( $\mathrm{M}=25.6 \%)$ was more frequent than artifact analogy $(\mathrm{M}=7.3 \%)$, which in turn was more frequent than human exceptionalism, which almost never occurred $(\mathrm{M}=0.3 \% ; F(2,88)=41.23, p<0.001$, $\eta^{2}=0.48$, Bonferroni-adjusted $p<0.001$.)

Teleological Language. Percentage of content minutes per class session containing teleological language did not differ by course audience for instructors at University $1(F(2,42)=0.45$, $p=0.640$; see Figure $6 \mathrm{~A})$ or instructors at University $2(F(2,42)$ $=0.02, p=0.983$; see Figure 6B).

Essentialist Language. Percentage of content minutes per class session containing essentialist language did not differ by course audience among instructors at University $1(F(2,42)=2.47, p=$ 0.115 ; see Figure $6 C$ ), but did among instructors at University $2\left(F(2,42)=4.12, p=0.023, \eta^{2}=0.16\right.$; see Figure 6D), where essentialist language was present in a higher percentage of content minutes per class in nonmajor courses than in lower-division majors courses (Tukey HSD $p<0.025$ ). These findings raise the possibility that relations between class level and essentialist language are different among instructors at the two universities. To test this hypothesis, we conducted a 3 (course audience) $\times 2$ (university) ANOVA to see whether a single pattern best characterized the data set as a whole, or whether the universities showed reliably different patterns. Results suggested that instructors at Universities 1 and 2 did indeed display reliably different patterns with respect to essentialist language and course audience (university $\times$ course audience interaction, $\left.F(2,84)=5.31, p=0.007, \eta^{2}=0.11\right)$.

Types of Essentialist Language. Essentialist language was divided into three subtypes: homogeneity, boundary intensification, and underlying cause (see Table 1). Among instructors at University 1 , the percentage of content minutes per class session containing language indicating homogeneity $(\mathrm{M}=4.9 \%)$ was higher than either underlying cause $(\mathrm{M}=2.1 \%)$ or boundary intensification $(\mathrm{M}=0.9 \%)$, which did not differ, $F(2,88)=$ 12.93, $p<0.001, \eta^{2}=0.23$, Bonferroni-adjusted $p<0.05$. Among instructors at University 2, percentage of content minutes per class session containing language indicating homogeneity $(M=6.7 \%)$ and underlying cause $(M=4.6 \%)$ did not differ, but both were more frequent than boundary intensification $(\mathrm{M}=$ $2.1 \%, F(2,88)=10.02, p<0.001, \eta^{2}=0.19$, Bonferroni-adjusted 
A. Teleological Language, University 1

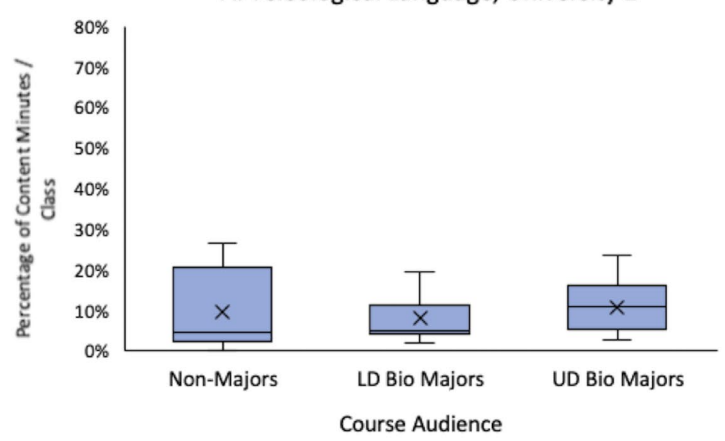

C. Essentialist Language, University 1

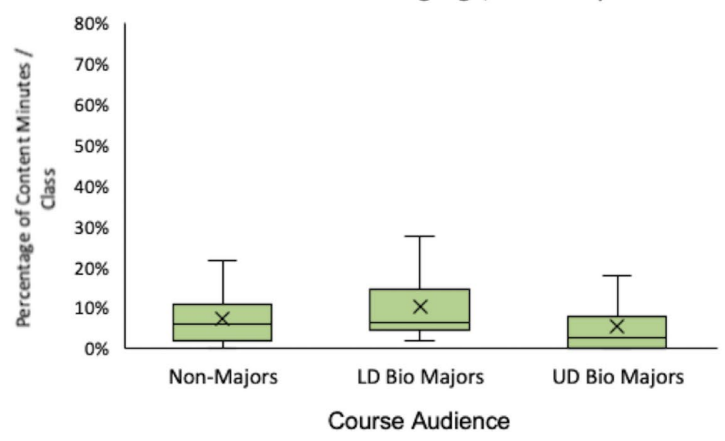

B. Teleological Language, University 2

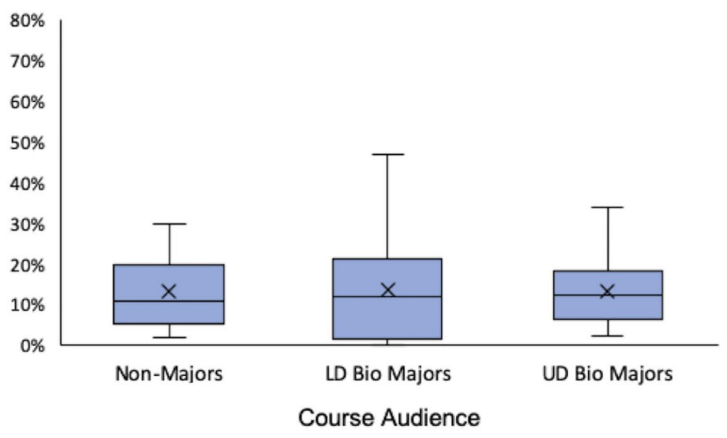

D. Essentialist Language, University 2

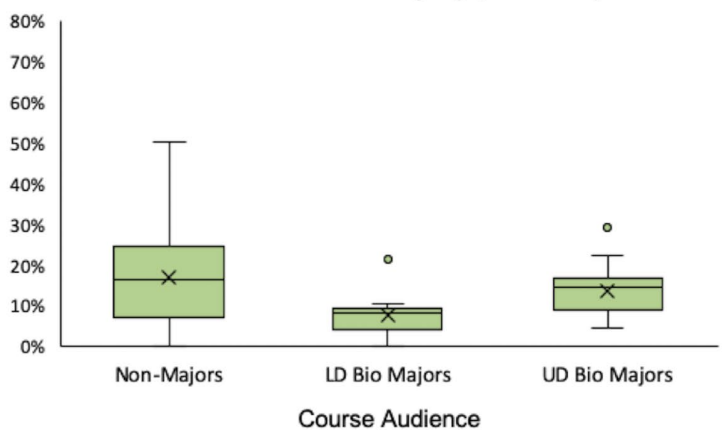

FIGURE 6. Mean percentage of content minutes containing teleological language (A, B) and essentialist language (C, D) per class session for courses targeted at nonmajors, lower-division (LD) biology majors, and upper-division (UD) biology majors at Universities 1 and 2.

$p<0.05)$. To test whether a single pattern best characterized the data set as a whole, or whether instructors at the two the universities showed reliably different patterns, we conducted a 3 (essentialism type) $\times 2$ (university) ANOVA. Results support a common pattern among instructors at both universities (specifically, analysis revealed a main effect of essentialism type $\left.\left[F(2,176)=21.57, p<0.001, \eta^{2}=0.20\right]\right)$ that did not interact with university $(F(2,176)=0.49, p=0.614)$. Follow-up tests on the combined data set suggest that percentage of content minutes per class session containing language indicating homogeneity $(M=5.9 \%)$ was higher than underlying cause $(M=3.4 \%)$, which in turn was higher than boundary intensification $(\mathrm{M}=$ $1.5 \%$, Bonferroni-adjusted $p<0.008$ ).

\section{DISCUSSION}

Cognitive construals - teleological, anthropic, and essentialist thinking-are pervasive and persistent ways of organizing informal, intuitive knowledge about biology and may provide the foundation for systems of related misconceptions among students learning biological science. At the same time, construal-consistent language may be helpful for learning in the science classroom. In the interest of understanding factors that might contribute to both positive and negative learning outcomes, our goal in this study was to examine the extent to which biology instructors used construal-consistent language across two universities and across courses aimed at a broad range of student audiences. Research questions included 1) Do university biology instructors use construal-consistent language in general? 2) To what extent does construal-consistent language vary by a) instructor or (b) intended class audience? 3) Are particular types of construal-consistent language more or less prevalent? 4) To what extent do particular types of construal-consistent language vary by a) instructor or b) intended class audience?

\section{Construal-Consistent Language Is Commonly Used by University Biology Instructors}

Coders scrutinized more than 4800 min of instructors' oral language about biology produced during formal class time from two very different universities and identified construal-consistent language in more than half of those minutes. Even at the very low end of the frequency range, such statements occurred at a rate of one every 6 minutes. All 18 instructors used language consistent with all three construals at some point during the sampled lecture content, and some type of construal-consistent language was present in every single class in our sample. Not only was anthropic language present in every class, but we also observed consistent use of teleological language, which was present in $97 \%$ of classes examined, and essentialist language, which was present in $90 \%$ of classes.

To be clear, we do not mean to suggest that instructors hold explicit misconceptions about the material that they are teaching. This is unlikely, as shown by the fact that they seldom agree with construal-consistent challenge statements (Richard et al., 2017; Fux et al., 2018) and deem explicitly teleological statements as inappropriate for biology textbooks (Nehm and Ridgway, 2011). Moreover, language can be construal consistent without necessarily conveying a misconception. For example, in Table 3, "The parasite that causes malaria..." is both consistent with the essentialist notion of a single underlying cause and also a true statement about the etiology of malaria. Nor are we suggesting that instructors are somehow responsible for 
their students' misconceptions; the goal of this research was not to investigate whether construal-consistent language is problematic. Instead, we see the results as a description of the educational environment that students encounter in the college biology classroom. Our results clearly show that construal-consistent language is a ubiquitous feature of that environment.

\section{Instructors' Use of Construal-Consistent Language Showed Surprisingly Little Variability}

The use of construal-consistent language was remarkably similar across both instructors and course audiences. At both universities, we found no differences between instructors with respect to their overall use of construal-consistent language, and few differences in their use of language consistent with specific construals - one instructor in University 2 stood out in terms of the use of teleological language, and one instructor from each university used essentialist language more than many of his or her peers. The overall use of teleological and anthropic language was no different for courses aimed at nonmajors than for courses aimed at lower-division or even upper-division majors (although anthropocentric and anthropomorphic language each varied by course audience, as discussed later). And in a rare case of diverging patterns between our two focal universities, essentialist language differed by course audience among instructors at University 2 but not University 1.

This remarkably uniform use of construal-consistent language across individual instructors and course audiences demonstrates the pervasive nature of these cognitive construals and reveals that construal-consistent language is used in teaching biology across a wide range of contexts by a variety of different experts. These findings extend previous evidence of instructors' use of teleological language in the high school classroom (e.g., Gresch and Martens, 2019) and anthropomorphic language in the elementary school classroom (e.g., Kallery and Psillos, 2004) to the university level and provide further evidence that construal-consistent language is a common way of talking about biology, even among experts in the field, in the biology classroom. As such, the role of instructors may not be to rid themselves of such language (which may be nigh impossible) but rather to help students navigate construal-consistent thinking and develop alternative scientific ways of thinking where appropriate-just like experts do (e.g., Goldberg and Thompson-Schill 2009; Nehm et al., 2010; Shtulman and Valcarcel, 2012). Similarly, Zohar and Ginossar (1998) proposed that science instructors should explicitly define terms for common patterns of thinking such as teleology and anthropomorphism to discuss their values and limitations (for a discussion, see Alters and Nelson, 2002)

Unexpectedly, we did observe markedly higher frequencies of construal-consistent language across the board at University 2 (the private East Coast university) than at University 1 (the public West Coast university). There are many possible explanations for this difference, including demographic differences across students and different instructor training and professional development programs across the two institutions. One salient potential explanation is that faculty at University 1 may be more explicitly aware of the role of cognitive construals in students' biological thinking because of the presence in the department of a laboratory devoted to discipline-based biology education research that investigates the role of cognitive con- struals in biology education, among other things. As such, the instructors from University 1 may therefore have been more likely to try to avoid using construal-consistent language in the classroom. However, it is important to emphasize that, despite differences in absolute levels of construal-consistent language, qualitative patterns within each university were surprisingly consistent, suggesting that these findings are likely to generalize broadly across different types of institutions.

\section{Anthropic Language Was the Most Commonly Observed Type of Construal-Consistent Language}

Anthropic language was present in every one of the 90 classes in our sample and occurred at roughly four times the rate of teleological or essentialist language. Moreover, unlike the other two types of construal-consistent language, subtypes of anthropic language varied in frequency based on course audience. Across institutions, anthropocentric language was more common in courses targeting nonmajors, whereas anthropomorphic language was more common in courses aimed at upper-division majors. One explanation for this pattern may be that instructors teaching courses for nonmajors use anthropocentric language as a pedagogical tool to make their lecture content more relevant or accessible to students lacking extensive biology background. Relatedly, instructors of upper-division courses may tend to use more anthropomorphic language to convey complex or unobservable (i.e., microscopic, abstract) concepts in those courses. Although these are merely speculation, the different use of anthropocentric and anthropomorphic language is clearly an important topic for further investigation.

Critically, the finding that anthropocentric and anthropomorphic language differ with respect to their relations to course audience validates our distinction between these two types of anthropic thinking. This finding is particularly noteworthy in the context of previous work investigating young children's anthropic thinking about biology. Byrne and colleagues (2009) found that using anthropocentric language was detrimental to students' understandings of beneficial microorganisms and decreased with age, whereas anthropomorphic language seemed to help children aged 7-14 convey their more complex understandings of microorganisms. Taking these findings into account, we might consider the persistent presence of anthropomorphic language in higher-level courses to be a useful pedagogical tool.

\section{How Might Instructors' Use of Construal-Consistent Language Impact Student Learning?}

Our results demonstrate that undergraduate-level biology instructors commonly used construal-consistent language in the classroom. However, our findings tell us little about the impact of such language on student outcomes. Although we can only speculate on the nature of these effects, there is reason to believe that they might be both beneficial and detrimental to student learning.

On one hand, instructors' use of construal-consistent language might make complex and abstract material more accessible to students and potentially capitalize on the use of cognitive construals to draw connections between informal (i.e., intuitive) and formal (i.e., scientific) understanding of biology (e.g., Evans and Rosengren, 2018). For example, analogies and 
metaphors are thought to be consistently used in science education as a bridge to understanding abstract concepts by anchoring these understandings in familiar or observable examples (see, e.g., Mason, 1994; for reviews, see Duit, 1991; Coll et al., 2005; Aubusson et al., 2006). As such, artifact analogies-a component of anthropocentric language-could facilitate student understanding of biology concepts. Similarly, the use of human examples in the science classroom-another component of anthropocentric language- - has also been shown to be a successful way to engage students and encourage learning. For example, Jacque et al. (2016) found that using human diseases as examples to teach biological concepts (e.g., evolution) increased the students' content knowledge about biology and their health literacy. Similarly, Pobiner and colleagues (2018) found that using human examples when teaching evolution in AP biology classes enhanced understanding of evolution compared with use of nonhuman examples. Taken together, these findings suggest that at least some forms of anthropocentric language (i.e., human examples, artifact analogy) might enhance student engagement and learning.

Another possibility is that construal-consistent language in the classroom might reinforce students' intuitive thinking about biology and thereby reify existing construal-consistent misconceptions. Anthropic, teleological, and essentialist thinking have been systematically linked to corresponding construal-consistent biological misconceptions (e.g., Bishop and Anderson, 1990; Moore et al., 2002; Shtulman, 2006; Shtulman and Schulz, 2008; Byrne et al., 2009; Kelemen and Rosset, 2009; Nehm and Ridgway, 2011; Kampourakis, 2014; Coley and Tanner, 2015; Coley et al., 2017b). As such, use of construal-consistent language by instructors could confirm students' intuitive but mistaken understandings. This consequence may stem from students' inability to distinguish between multiple possible meanings (i.e., literal and figurative) of terms across different contexts. Nehm and colleagues (2010) found that students were not always able to make such differentiations, although experts were. Indeed, students' interpretation of instructors' expressed meanings-especially in the case of potentially ambiguous terms-are "filtered through" their own intuitive conceptual systems, and therefore can be discordant with the intended meaning of the instructor (Rector et al., 2013). Alternatively, construal-consistent language could indirectly reinforce such misconceptions by failing to contradict or challenge construal-consistent misconceptions. Indeed, Gouvea and Simon (2018) show that directly challenging such misconceptions using written language can reduce student acceptance thereof.

Although investigating the effects of construal-consistent language are beyond the scope of the current investigation, a critically important priority for future research is to sort out the ways that construal-consistent language might facilitate learning biology and the ways in which it might interfere with the acquisition of a scientific understanding of biological concepts. We suspect the answer will be complicated.

\section{Despite the Abundance of Construal-Consistent Language, Some Common Construal-Consistent Misconceptions Were Conspicuously Absent from Instructor Speech}

In this study, we anticipated finding language consistent with specific misconceptions previously associated with intuitive reasoning. However, this was not always the case, suggesting that some patterns of intuitive thinking are not related to instructor language. One example is the phenomenon of boundary intensification. Boundary intensification is a consequence of essentialist thinking; belief in an underlying category essence has been linked to exaggeration of differences between categories as well as homogeneity within categories (e.g., Diesendruck and Gelman, 1999; Rhodes and Gelman, 2009; Coley et al., 2017a), leading to the perception that categories have sharp, well-defined boundaries and all-or-none membership. Although not necessarily a misconception per se, this bias can lead to systematic biological misconceptions, such as those stemming from difficulty in understanding that plants and animal share many important features (e.g., Richards and Siegler, 1986; Coley et al., 2017a). While such exaggeration of category boundaries has been documented in children (e.g., Herrmann et al., 2013) and undergraduates (for a review, see Gelman and Rhodes, 2012), it was rarely seen in our corpus, accounting for only $1.5 \%$ of content minutes. The fact that our sampled undergraduate biology instructors rarely used language consistent with boundary intensification, coupled with its prevalence among biological novices, suggests that this assumption is something that students bring with them into the biology classroom.

Another misconception that we commonly see in undergraduates is human exceptionalism - the belief that humans are biologically exceptional and separate from other species (Coley, 2007; Pickering, 2008; Gee, 2013). For example, 38\% of Shtulman's (2006) sample of high school and undergraduate students agreed with the statement "the origin of human beings requires a different explanation than the origin of other species." However, instructors in our sample almost never used language consistent with human exceptionalism (such language was present in only $0.4 \%$ of content minutes). Thus, both boundary intensification and human exceptionalism represent construal-consistent patterns of thought that are common among students and that may give rise to biological misconceptions but were virtually absent from instructors' classroom language. These inconsistencies between instructor language and students' misconceptions suggest that students may acquire and maintain these misconceptions informally via everyday interactions with the world, without influence from instructors' oral language in biology classrooms.

\section{Future Directions}

These findings raise a number of important questions for future research. First and foremost, it will be critical to evaluate potential positive and negative impacts of construal-consistent language on student learning in biology. While we have speculated about potential effects of construal-consistent language on learning outcomes, future research should directly investigate how exposure to this language in a formal learning environment influences students' understanding of biological concepts. Likewise, our results do not tell us whether instructors employ construal-consistent language consciously as a pedagogical tool, or whether they do so unconsciously as the result of an interplay between conscious attempts to make material accessible and their own implicit construal-consistent intuitive biological conceptions, which we know persist despite advanced formal training (e.g., Goldberg and Thompson-Schill, 2009; 
Kelemen and Rosset, 2009; Shtulman and Harrington, 2016). Similarly, our findings do not speak to instructors' intended meanings when they use construal-consistent language in the classroom or how students interpret this type of instructor language (Rector et al., 2013). An important next step could be to investigate these intentions and interpretations and determine factors that predict successful interpretations of the intended message. On a more specific level, the different roles of anthropocentric and anthropomorphic instructor language in courses aimed at novice versus advanced students warrants further investigation. Of particular interest is the possibility that extensive use of human examples may render material more relevant for students while simultaneously reinforcing possible implicit beliefs endorsing human exceptionalism. Additionally, we sampled a broad range of course topics and levels, but it is quite possible that systematic linkages might exist between specific topics and particular types of construal-consistent language. For instance, teleological language might be commonly employed by instructors in units on ecological relationships (see, e.g., Voute, 1968; Waxman and Medin, 2013), whereas essentialist language might be evident in units on genetics (Dar-Nimrod and Heine, 2011) or taxonomy (Hull, 1965; Coley and Muratore, 2012). Moreover, future research could examine whether construal-consistent language is differentially considered appropriate across various courses and biological topics, and whether instructors' use of construal-consistent language mirrors judgments of contextual appropriateness. Such research could also speak to instructors' awareness of the place of cognitive construals in the biology classroom.

\section{CONCLUSIONS}

Overall, this research demonstrates that instructors commonly use construal-consistent language when teaching undergraduate biology courses. The use of such language is remarkably consistent across instructors, course audiences, and markedly different kinds of institutions. This raises important questions about how the presence of construal-consistent language in the college classroom may facilitate learning, and how it may reinforce construal-consistent systems of misconceptions. Together, the answers to these and related questions should allow us to better understand learning and teaching biology as a complex interaction between input from instructors and students' existing conceptual understanding.

\section{ACKNOWLEDGMENTS}

This research was supported with funds by National Science Foundation (EHR Education Core Research [ECR] Grant \#DGE 153549) to J.D.C. and K.D.T. This research would not have been possible without the contributions of J.R. Blair, Kostia Bergman, Dana Byrd, Mark Chan, Veronica Godoy-Carter, Holly Harris, Brian Helmuth, Jenn Ingemi, Jonathan Knight, Lance Lund, Michelle McCully, Missy McElligott, Sally Pasion, Robert Patterson, MarySusan Potts-Santone, Christopher Richardson, Kevin Simonin, Andrea Swei, and Michelle Zee.

\section{REFERENCES}

Ahn, W., Kalish, C., Gelman, S. A., Medin, D. L., Luhmann, C., Atran, C., ... \& Shafto, P. (2001). Why essences are essential in the psychology of concepts. Cognition, 82(1), 59-69.

Alters, B. J., \& Nelson, C. E. (2002). Perspective: Teaching evolution in higher education. Evolution, 56(10), 1891-1901
Arenson, M., \& Coley, J. D. (2018). Anthropocentric by default? Attribution of familiar and novel properties to living things. Cognitive Science, 42(1), $1-33$.

Aubusson, P. J., Harrison, A. G., \& Ritchie, S. M. (2006). Metaphor and analogy. In Aubusson, P. J., Harrison, A. G., \& Ritchie, S. M. (Eds.), Metaphor and analogy in science education (Science \& Technology Education Library, 30, pp. 1-9). Dordrecht, Netherlands: Springer.

Bishop, B. A., \& Anderson, C. W. (1990). Student conceptions of natural selection and its role in evolution. Journal of Research in Science Teaching. 27(5), 415-427.

Blancke, S., \& De Smedt, J. (2013). Evolved to be irrational? Evolutionary and cognitive foundations. In Pigliucci, M., \& Boundry, M. (Eds.), Philosophy of pseudoscience: Reconsidering the demarcation problem (pp. 341379). Chicago, IL: University of Chicago Press.

Boeije, H. (2002). A purposeful approach to the constant comparative method in the analysis of qualitative interviews. Quality and Quantity, 36(4), 391-409.

Brandon, R. N. (1981). Biological teleology: Questions and explanations Studies in History and Philosophy of Science Part A, 12(2), 91-105.

Byrne, J., Grace, M., \& Hanley, P. (2009). Children's anthropomorphic and anthropocentric ideas about micro-organisms: Educational research. Journal of Biological Education, 44(1), 37-43.

Coley, J. D. (2007). The human animal: Developmental changes in judgments of taxonomic and psychological similarity among humans and other animals. Cognition, Brain, Behavior, 11, 733-756.

Coley, J. D., Arenson, M., Xu, Y., \& Tanner, K. D. (2017a). Intuitive biological thought: Developmental changes and effects of biology education in late adolescence. Cognitive Psychology, 92, 1-21.

Coley, J. D., Betz, N., Leffers, J., Xu, Y., Fux, M., de Nesnara, K., \& Tanner, K. (2017b). Relations between intuitive biological thought and scientific misconceptions. Poster presented at: 39th annual meeting of the Cognitive Science Society (London, UK)

Coley, J. D., \& Muratore, T. M. (2012). Trees, fish, and other fictions: Folk biological thought and its implications for understanding evolutionary biology. In Rosengren, K. S., Brem, S., Evans, E. M., \& Sinatra, G. (Eds.), Evolution challenges: Integrating research and practice in teaching and learning about evolution (pp. 22-46). New York: Oxford University Press.

Coley, J. D., \& Tanner, K. (2015). Relations between intuitive biological thinking and biological misconceptions in biology majors and nonmajors. CBE-Life Sciences Education, 14(1), ar8.

Coley, J. D., \& Tanner, K. D. (2012). Common origins of diverse misconceptions: Cognitive principles and the development of biology thinking. CBE-Life Sciences Education, 11(3), 209-215.

Coll, R. K., France, B., \& Taylor, I. (2005). The role of models/and analogies in science education: Implications from research. International Journal of Science Education, 27(2), 183-198.

Dar-Nimrod, I., \& Heine, S. J. (2011). Genetic essentialism: On the deceptive determinism of DNA. Psychological Bulletin, 137(5), 800.

Diesendruck, G., \& Gelman, S. A. (1999). Domain differences in absolute judgments of category membership: Evidence for an essentialist account of categorization. Psychonomic Bulletin \& Review, 6(2), 338-346.

Duit, R. (1991). On the role of analogies and metaphors in learning science. Science Education, 75(6), 649-672

Eidson, R. C., \& Coley, J. D. (2014). Not so fast: Reassessing gender essentialism in young adults. Journal of Cognition and Development, 15(2), $382-$ 392.

Evans, E. M. (2008). Conceptual change and evolutionary biology: A developmental analysis. International Handbook of Research on Conceptual Change, 263-294.

Evans, E. M., \& Rosengren, K. S. (2018). Cognitive biases or cognitive bridges? Intuitive reasoning in biology. In Kompourakis, K., \& Reiss, M. J. (Eds.), Teaching biology in schools (pp. 9-21). New York: Routledge.

Fux, M., de Nesnera, K., Xu, Y., Betz, N., Leffers, J., Tanner, K., \& Coley, J. D. (2018). Demonstrating contingency between intuitive biological reasoning and perpetual biological misconceptions across levels of academic expertise. Poster presented at: 30th meeting of the Association for Psychological Science (San Francisco, CA).

Gee, H. (2013). The accidental species: Misunderstandings of human evolution. Chicago: University of Chicago Press. 
Geelan, D. (2012). Teacher explanations. In Fraser, B., Tobin, K., \& McRobbie, C. J. (Eds.), Second international handbook of science education (pp. 987-999). Dordrecht, Netherlands: Springer.

Gelman, S. A. (2003). The essential child: Origins of essentialism in everyday thought (Oxford series in cognitive development). New York: Oxford University Press.

Gelman, S. A. (2004). Psychological essentialism in children. Trends in Cognitive Sciences, 8(9), 404-409.

Gelman, S. A., Coley, J. D., \& Gottfried, G. M. (1994). Essentialist beliefs in children: The acquisition of concepts and theories. In Hirschfeld, L. A., \& Gelman, S. A. (Eds.), Mapping the mind: Domain specificity in cognition and culture (pp. 341-365). New York: Cambridge University Press.

Gelman, S. A., \& Rhodes, M. (2012). Two-thousand years of stasis. How psychological essentialism impedes evolutionary understanding. In Rosengren, K. S., Brem, S., Evans, E. M., \& Sinatra, G. (Eds.), Evolution challenges: Integrating research and practice in teaching and learning about evolution (pp. 3-21). Oxford: Oxford University Press.

Gest, S. D., Holland-Coviello, R., Welsh, J. A., Eicher-Catt, D. L., \& Gill, S. (2006). Language development subcontexts in Head Start classrooms: Distinctive patterns of teacher talk during free play, mealtime, and book reading. Early Education and Development, 17(2), 293-315.

Glaser, B. G., \& Strauss, A. L. (1967). The discovery of grounded theory: Strategies for qualitative research. Chicago: Aldine.

Goldberg, R. F., \& Thompson-Schill, S. L. (2009). Developmental "roots" in mature biological knowledge. Psychological Science, 20(4), 480-487.

Gouvea, J. S., \& Simon, M. R. (2018). Challenging cognitive construals: A dynamic alternative to stable misconceptions. CBE-Life Sciences Education, 17(2), ar34.

Gresch, H., \& Martens, M. (2019). Teleology as a tacit dimension of teaching and learning evolution: A sociological approach to classroom interaction in science education. Journal of Research in Science Teaching, 56(3), 243-269.

Ha, M., \& Nehm, R. H. (2014). Darwin's difficulties and students' struggles with trait loss: Cognitive-historical parallelisms in evolutionary explanation. Science \& Education, 23(5), 1051-1074.

Herrmann, P. A., French, J. A., DeHart, G. B., \& Rosengren, K. S. (2013). Essentialist reasoning and knowledge effects on biological reasoning in young children. Merrill-Palmer Quarterly, 59(2), 198-220.

Hull, D. L. (1965). The effect of essentialism on taxonomy-two thousand years of stasis (I). British Journal for the Philosophy of Science, 15(60), 314-326.

Jacque, B., Koch-Weser, S., Faux, R., \& Meiri, K. (2016). Addressing health literacy challenges with a cutting-edge infectious disease curriculum for the high school biology classroom. Health Education \& Behavior, 43(1), 43-53.

Kallery, M., \& Psillos, D. (2004). Anthropomorphism and animism in early years science: Why teachers use them, how they conceptualise them and what are their views on their use. Research in Science Education, 34(3), 291-311.

Kampourakis, K. (2014). Understanding evolution. New York: Cambridge University Press.

Keil, F. (2006). Explanation and understanding. Annual Review of Psychology, $57,227-254$.

Kelemen, D. (2012). Teleological minds: How natural intuitions about agency and purpose influence learning about evolution. In Rosengren, K. S., Brem, S., Evans, E. M., \& Sinatra, G. (Eds.), Evolution challenges: Integrating research and practice in teaching and learning about evolution (pp. 66-92). Oxford: Oxford University Press.

Kelemen, D., \& Rosset, E. (2009). The human function compunction: Teleological explanation in adults. Cognition, 111(1), 138-143.

Kelemen, D., Rottman, J., \& Seston, R. (2013). Professional physical scientists display tenacious teleological tendencies: Purpose-based reasoning as a cognitive default. Journal of Experimental Psychology: General, 142(4), 1074-1083

Lennox, J. G. (1993). Darwin was a teleologist. Biology and Philosophy, 8(4), 409-421.

Lennox, J. G., \& Kampourakis, K. (2013). Biological teleology: The need for history. In Kampourakis, K. (Ed.), The philosophy of biology (pp. 421454). Dordrecht, Netherlands: Springer.
Mason, L. (1994). Cognitive and metacognitive aspects in conceptual change by analogy. Instructional Science, 22(3), 157-187.

Mayr, E. (1982). The growth of biological thought: Diversity, evolution, and inheritance. Cambridge, MA: Harvard University Press.

Medin, D. L., \& Atran, S. (2004). The native mind: Biological categorization and reasoning in development and across cultures. Psychological review, 111(4), 960.

Medin, D. L., \& Ortony, A. (1989). Psychological essentialism. In Vosniadou, S., \& Ortony, A. (Eds.), Similarity and analogical reasoning (pp. 179-195) Cambridge: Cambridge University Press.

Moore, R., Mitchell, G., Bally, R., Inglis, M., Day, J., \& Jacobs, D. (2002). Undergraduates' understanding of evolution: Ascriptions of agency as a problem for student learning. Journal of Biological Education, 36(2), 65-71

Nehm, R. H., Rector, M. A., \& Ha, M. (2010). "Force-talk" in evolutionary explanation: Metaphors and misconceptions. Evolution: Education and Outreach, 3(4), 605

Nehm, R. H., \& Ridgway, J. (2011). What do experts and novices "see" in evolutionary problems? Evolution: Education and Outreach, 4(4), 666-679.

Nehm, R. H., \& Schonfeld, I. S. (2007). Does increasing biology teacher knowledge of evolution and the nature of science lead to greater preference for the teaching of evolution in schools? Journal of Science Teacher Education, 18(5), 699-723.

Nettle, D. (2010). Understanding of evolution may be improved by thinking about people. Evolutionary Psychology, 8(2). 147470491000800206.

Piaget, J. (1929). The child's conception of the world. New York: Harcourt, Brace Jovanovich

Pickering, A. (2008). Against human exceptionalism. Paper presented at: a workshop on "What Does it Mean to Be Human?" (University of Exeter, UK, January 25, 2008). Retrieved March 1, 2018, from http://hdl.handle net/10036/18873

Pobiner, B. (2016). Accepting, understanding, teaching, and learning (human) evolution: Obstacles and opportunities. American Journal of Physical Anthropology, 159, 232-274.

Pobiner, B., Beardsley, P. M., Bertka, C. M., \& Watson, W. A. (2018). Using human case studies to teach evolution in high school AP biology classrooms. Evolution: Education and Outreach, 11(1), 3.

Quinn, F., Castéra, J., \& Clément, P. (2016). Teachers' conceptions of the environment: Anthropocentrism, non-anthropocentrism, anthropomorphism and the place of nature. Environmental Education Research, 22(6), 893-917.

Rector, M. A., Nehm, R. H., \& Pearl, D. (2013). Learning the language of evolution: Lexical ambiguity and word meaning in student explanations. Research in Science Education, 43(3), 1107-1133.

Rehder, B., \& Burnett, R. C. (2005). Feature inference and the causal structure of categories. Cognitive Psychology, 50(3), 264-314.

Rhodes, M., \& Gelman, S. A. (2009). Five-year-olds' beliefs about the discreteness of category boundaries for animals and artifacts. Psychonomic Bulletin \& Review, 16(5), 920-924.

Richard, M., Coley, J. D., \& Tanner, K. D. (2017). Investigating undergraduate students' use of intuitive reasoning and evolutionary knowledge in explanations of antibiotic resistance. CBE-Life Sciences Education, 16(3), $\operatorname{ar} 55$

Richards, D. D., \& Siegler, R. S. (1986). Children's understandings of the attributes of life. Journal of Experimental Child Psychology, 42(1), 1-22.

Ruse, M. (2000). Teleology: Yesterday, today, and tomorrow? Studies in History and Philosophy of Science Part C: Studies in History and Philosophy of Biological and Biomedical Sciences, 31(1), 213-232.

Shtulman, A. (2006). Qualitative differences between naïve and scientific theories of evolution. Cognitive Psychology, 52(2), 170-194.

Shtulman, A., \& Harrington, K. (2016). Tensions between science and intuition across the lifespan. Topics in Cognitive Science, 8(1), 118-137.

Shtulman, A., \& Lombrozo, T. (2016). Bundles of contradiction: A coexistence view of conceptual change. In Barner, D., \& Baron, A. S. (Eds.), Core knowledge and conceptual change (pp. 53-72). New York: Oxford University Press.

Shtulman, A., \& Schulz, L. (2008). The relation between essentialist beliefs and evolutionary reasoning. Cognitive Science, 32(6), 1049-1062. 
Shtulman, A., \& Valcarcel, J. (2012). Scientific knowledge suppresses but does not supplant earlier intuitions. Cognition, 124(2), 209-215.

Sinatra, G. M., Brem, S. K., \& Evans, E. M. (2008). Changing minds? Implications of conceptual change for teaching and learning about biological evolution. Evolution: Education and Outreach, 1(2), 189-195.

Stern, F., Kampourakis, K., Huneault, C., Silveira, P., \& Müller, A. (2018). Undergraduate biology students' teleological and essentialist misconceptions. Education Sciences, 8(3), 135.

Talanquer, V. (2007). Explanations and teleology in chemistry education. International Journal of Science Education, 29(7), 853-870.

Talanquer, V. (2013). When atoms want. Journal of Chemical Education, 90(11), 1419-1424.

Tamir, P., \& Zohar, A. (1991). Anthropomorphism and teleology in reasoning about biological phenomena. Science Education, 75(1), 57-67.
Treagust, D. F., \& Harrison, A. G. (2000). In search of explanatory frameworks: An analysis of Richard Feynman's lecture "Atoms in motion." International Journal of Science Education, 22(11), 1157-1170.

Voute, A. D. (1968). Ecology as a teleological science. Acta Biotheoretica, 18(1), 143-164.

Waxman, S. R., \& Medin, D. L. (2013). Teleological reasoning about nature: Intentional design or relational perspectives?. Trends in Cognitive Sciences, 17(4), 166-171.

Zhang, Y., \& Wildemuth, B. M. (2009). Qualitative analysis of content. Applications of Social Research Methods to Questions in Information and Library Science, 308, 319

Zohar, A., \& Ginossar, S. (1998). Lifting the taboo regarding teleology and anthropomorphism in biology education-heretical suggestions. Science Education, 82(6), 679-697. 